\title{
All Changed, Changed Utterly? Irish General Election Boundary Amendments and the 2012 Constituency Commission Report
}

\author{
ADRIAN KAVANAGH \\ Department of Geography, NUI Maynooth, Ireland
}

\begin{abstract}
The 2012 Constituency Commission report has recommended a reduction in the number of Dáil deputies from 166 to 158 and the number of general election constituencies from 43 to 40, while bringing about changes - some very fundamental in scope - to the majority of the existing Dáil constituencies. These changes are detailed in this article, while being placed in the context of previous electoral boundary amendments throughout the history of the Irish state and the processes employed in other states, such as the United Kingdom. The oft quoted contention that the 2012 boundary revisions are the most considerable in scope since those of 1980 is tested and proven with reference to the use of the Kavanagh index of constituency change (KICC scores), with these KICC scores also employed to highlight the regions and constituencies that have been most prone to boundary amendments over the past three decades.
\end{abstract}

Keywords: Constituency Commission; election boundaries; geography

\section{Introduction}

The 2012 Constituency Commission report, recommending new constituency boundaries for the next Dáil (general) elections, ultimately marks the effective start of a long campaign leading up to the next election. Differential levels of population change across the state between 1996 and 2006 (as measured in the 2002 and 2006 Census reports) had proved to be the main driver of boundary changes in the previous two (2004 and 2007) reports. However, while population change again played a key role in shaping the changes made in the 2012 report, the main impulse for change related more so to the government's decision to reduce the number of seats in Dáil Éireann. The changes recommended in this report are of course of great interest to

Correspondence Address: Adrian Kavanagh, Department of Geography, NUI Maynooth, Maynooth, Ireland. Email:adrian.p.kavanagh@nuim.ie 
the different political parties and individual politicians for whom a boundary change might greatly affect their future electoral prospects, even to the point of effectively ending their Dáil careers. The report is also likely to have a particular bearing on the areas involved and their representation levels, as well as levels of political engagement and participation in such areas. These could also have an impact on the extent to which certain political reform initiatives such as gender quotas are effectively implemented.

\section{The Irish Electoral Boundary Redrawal Process in Context}

Changes to electoral boundaries in Ireland prior to the 1977 election were generally made along partisan lines (with Fianna Fáil dominating this process owing to the fact that this party generally formed the government for much of the period between the early 1930s and the 1970s). The main trend evident in the earlier boundary amendments involved a reduction in district magnitude levels (Figure 1). The 1923 revision involved an average district magnitude level of 5.25 seats per constituency and encompassed a number of large (seven-, eight- and nine-seat) constituencies. But subsequent revisions saw the extinction of these and brought about an increase in the number of three-seat constituencies (the smallest constituency size permitted under the Irish constitution). The number of three-seat constituencies increased from six in 1923 to 26 in the partisan revisions of 1969 and 1974, before falling again once independent commissions took charge of the process from 1980 onwards. Such changes favoured the two larger parties, Fianna Fáil and Fine Gael, as these parties would be expected to gain electorally, especially relative to the smaller parties, from the larger number of smaller (three-seat) constituencies, in which the share of

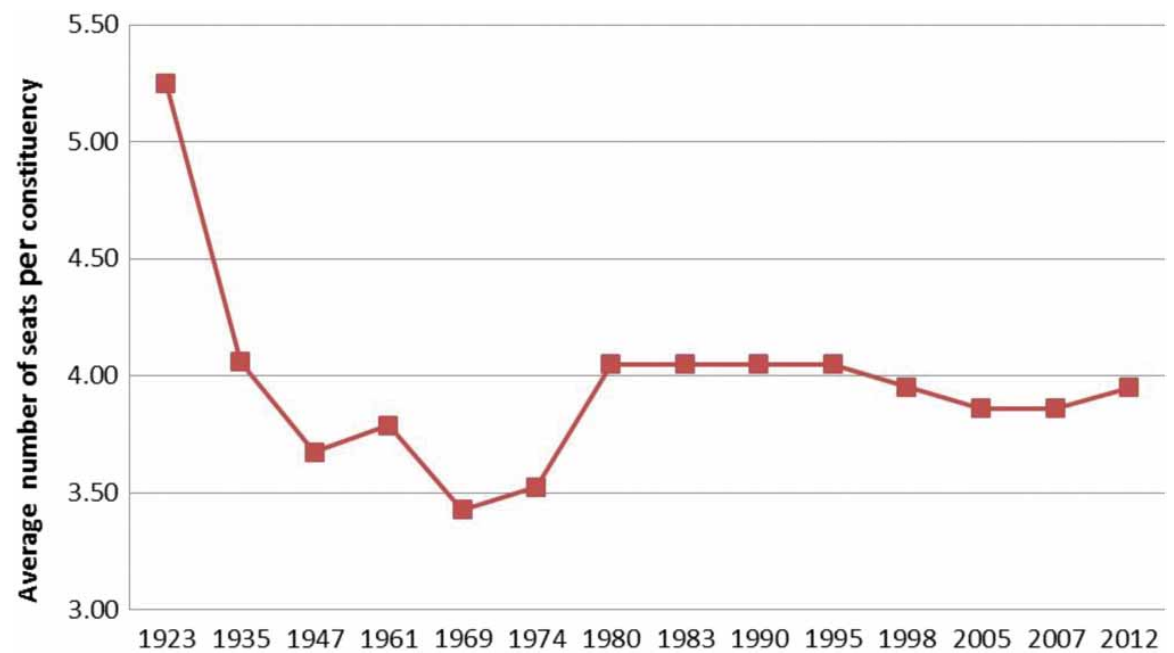

Figure 1. Average seat levels per constituency by Dáil boundary revision, 1923-2012 
the vote required to win seats would be higher than in larger constituencies and beyond the reach of the smaller political groupings in most cases. In the four elections held after the 1933 revisions, Fianna Fáil won 6.5 more seats than it would have if its share of Dáil seats had been exactly proportional to the first preference votes won by Fianna Fáil in these contests (Coleman, 2007: 163).

Long periods between boundary revisions (with an average gap of 12 years between revisions up to the late 1960s), differential levels of population decline across the state (with particularly high levels in the west) and a degree of malapportionment led to significant variations in average population per Dáil deputy levels between different constituencies in the decades leading up to the 1960s (Central Statistics Office, 1950, 1957). The more rural and western constituencies tended, as a result, to be over-represented relative to those in Dublin and the east, with the 1956 Census showing the average population per Dáil deputy level in Dublin (23,526 people per Dáil deputy) to be 19.3 per cent above the national average representation level $(19,716)$ and 34.5 per cent above the average level in the ConnachtUlster constituencies (17,490) (Central Statistics Office, 1957). A controversial boundary revision introduced by the Fianna Fáil government in 1959 proposed to maintain this inbuilt bias in favour of western constituencies on the basis of a proposal that constituency area should also be taken into account in the revision process. But these proposals were later withdrawn after the constitutionality of this 1959 Act was successfully challenged in the High Court by Senator John O'Donovan on the equality of representation principle established in relation to Dáil constituencies by Article 16.2 of the Irish constitution.

The O'Donovan decision also prompted efforts to bring Dáil deputy per population ratios more in line with the national average. The 'micromanagement of constituency boundaries' that resulted was associated with increased attempts by government parties to manipulate these constituency boundaries for their political advantage, resulting in a significant increase in the breaching of county boundaries in the process (Coakley, 2007: 9). The degree of bias produced by these gerrymanders was also shaped by other considerations, such as changing party support or competition levels and vote transfer patterns, and some gerrymanders proved to be decidedly less successful. The successful gerrymander brought in by the Fianna Fáil Minister for Local Government Kevin Boland with the 1969 revisions (the 'Bolander') helped his party to win a clear overall majority in the 1969 election even though Fianna Fáil's vote share was lower than the combined vote share won by the main opposition parties, Fine Gael and Labour. Fianna Fáil's success in that election, however, was not solely down to the 'Bolander', but was also due to the weakness of vote transfers between the main opposition parties and the especially large number of Labour Party candidates contesting that election, many of whom won relatively small vote levels. The effect of these revisions was decidedly blunted in the subsequent 1973 contest by the opposition parties' decision to fight that election on a common platform, meaning that vote transfers between the two parties improved as a result and this helped the coalition parties to win that election. The most controversial (and ultimately least successful) of the gerrymanders was the 1974 boundary 
revisions brought in by the Minister for Local Government in the Fine Gael-Labour coalition government, James Tully. These had been expected to bias the results of the following general election significantly in favour of the coalition parties and especially Labour, but an unanticipated large swing to Fianna Fáil in the 1977 general election meant that the effect of the gerrymander actually worked in favour of the opposition party. The spectacular failure of the Tully gerrymander left the Fine Gael-Labour government liable to 'go down in world history as probably the only government ever to implement a gerrymander which favoured the opposition' (Gallagher, 1986: 260) and gave rise to a new term in the political science literature, the 'Tullymander'. However, it did not prove an outright failure as it did succeed in limiting Labour Party seat losses (albeit at the expense of that party's coalition partner, Fine Gael) in the 1977 election.

Promises were made by Fianna Fáil during the 1977 campaign to put an independent body in charge of future constituency boundary revisions, and these were implemented after the Lynch government regained power at that election. These independent commissions were initially established on an ad hoc basis, starting with the 1980 boundary revisions. The 1997 Electoral Act placed these independent commissions on a statutory basis as a permanent Constituency Commission, to be chaired by a Judge of the High Court, and whose membership would also consist of the Ombudsman, the Secretary General of the Department of Environment and Local Government, the Clerk of Dáil Éireann and the Clerk of Seanad Éireann. The frequency of constituency boundary revisions has increased dramatically since the establishment of the independent commissions, with nine boundary reports produced over the three following decades, commencing with the 1980 report (although the 1988 report was never implemented due to opposition party protests against the amending of the terms of reference for the 1988 commission to more or less eliminate five-seat constituencies), as compared with a total of just six reports across the period 19231980.

\section{The 2012 Constituency Commission Report}

The changed context faced by the 2011/12 Constituency Commission was shaped by a government decision to reduce Dáil seat numbers, but also by a High Court challenge taken by independent Dáil deputies Finian McGrath and Catherine Murphy against the constitutionality of the constituency boundaries used for the 2007 general election. Drawn up in the 2004 Constituency Commission report, these were based on 2002 Census population by area figures, but a new census (the 2006 Census) had already taken place in the intervening period and provisional Census 2006 population by area figures had been made available some months before the general election took place (with definitive census figures released two months before this on 29 March 2007). These figures outlined significant variations in terms of Dáil deputy per population ratios across constituencies. The three-seat Dublin West constituency $(92,900)$ was found to have a larger population than the four-seat Cork North-Central $(91,591)$, while four-seat Dublin North $(120,309)$ had 
a larger population than a number of five-seat constituencies (Cavan-Monaghan (120,000), Dublin South (118,704), Limerick East $(118,235)$ and Dún Laoghaire $(114,166))$, with the populations of these being significantly lower than that of the largest five-seat constituency, Laois-Offaly (137,927) (Central Statistics Office, 2007: 39). The High Court rejected the claims, arguing that it was "not practicable between the publication of the final (census) figures on March $29^{\text {th }}$ and when the Dáil was dissolved (April $29^{\text {th }}$ ) to ensure the process of amending legislation was completed in time for the general election' (Carolan, 2007: 7).

The judgment, however, argued for a change in the process of redrawing electoral boundaries. Noting the limited differences between provisional and definitive population census figures for large geographical units such as Dáil constituencies, the judgment argued that the process of establishing a Constituency Commission should commence after the publication of provisional population by area census figures (usually released a few months after the holding of a census) with the proviso that recommendations based on these be checked against the final population by area figures before a new Constituency Commission report is published (Carty, 2007; Carolan, 2007). This finding was given a statutory basis as part of the 2009 Electoral (Amendment) Act and ensured that the process of redrawing electoral boundaries based on the 2011 Census figures would commence at a much earlier stage than that of previous revisions.

The other key development that would ultimately shape the 2011/12 Commission's work was an announcement by the Fine Gael leader Enda Kenny at the 2009 MacGill Summer School that he was planning a reduction in Dáil seat numbers should Fine Gael take power following the next election. He suggested that, allowing for provisions to help preserve county boundaries and the need to take account of new population figures at the following census, there was scope for reduction in Dáil seat numbers of 'somewhere in between 10 and 20' (de Bréadún, 2009: 8). This was later interpreted by some commentators as a cast-iron Fine Gael promise to reduce Dáil seat numbers by 20. But they failed to note that the potential for seat reductions would be limited by any population increase at Census 2011 given the constitutional provision for there to be one Dáil deputy for no more than 30,000 people on average within the state.

The 2012 Constituency Commission, the fourth under the terms of the 1997 Electoral Act, was established on 27 July 2011 after the publication of the provisional Census 2011 population by area figures. The terms of reference for Dáil constituency boundaries were set out in Section 6 of the Electoral Act and the various amendments to this, including the 2011 amendment, which reduced the range of seat numbers that the Commission could opt of from the old 164-168 seat range to a new range of between 153 and 160 seats. As has been the case since the 1947 boundary revisions, constituencies comprised of contiguous areas were to be represented by between three and five Dáil deputies. The breaching of county boundaries, as far as would be practicable, was to be avoided in the drawing of electoral boundaries, while due regard was also to be taken of significant physical features and population density levels The Commission was also required to try, as far as was practicable, to 
ensure continuity with the previous boundary configuration and to ensure that the ratio between the number of TDs and population in constituencies was similar across the state. The latter provision usually acts as the basis under which a Constituency Commission is required to make changes to existing electoral boundaries, and indeed significant variations existed between the old Dáil constituencies in terms of their population per Dáil deputy levels based on the Census 2011 figures, as illustrated by Figure 2 .

In this revision, however, the requirement to reduce Dáil seat numbers by between six and 13 was an even more significant factor in shaping the changes than that of population change. Constituency Commissions generally attempt to ensure that the deputy per population ratio for all the recommended constituencies fall within a 5 per cent range of the national average representation level. Derogations from this 5 per cent limit had been permitted in past reports up to a maximum variance of 7.89 per cent - a precedent set by the level of variance associated with the Mayo East constituency in the 1983 Commission's recommendations. Such instances mainly involved cases where county boundaries would otherwise have been breached, as occurred in relation to the Louth and Cavan-Monaghan constituencies in the 2004 revisions and Cavan-Monaghan again in the 2007 revisions.

In relation to population trends, the significant level of population growth associated with the Celtic Tiger period of economic growth in the periods leading up to the 1996 and 2002 Censuses was shown to have continued into the intercensal period leading up to the 2011 Census, which showed that the state population had reached $4,588,252$, marking an increase of 348,084 , or 8.1 per cent, on the 2006 figure. The somewhat unanticipated level of population increase meant that the Fine Gael proposals to reduce Dáil seat numbers had to be tempered, as the minimum number of deputies possible given the constitutional stipulation to have at least one Dáil deputy per 30,000 population would now be 153, having been 142 following Census 2006. Notable geographical variations were evident across the country in terms of this population change, with especially high levels of increase again being evident in commuter belt counties such as Laois and Fingal and less marked levels of increase found in other parts of the state, and this geography of population change would feed into the decisions taken by the Commission.

The level of change associated with the present Constituency Commission report was the most dramatic since the 1980 revision brought about an increase in Dáil seat numbers from 148 to 166 . The Commission decided to reduce Dáil seat numbers by eight, while the number of Dáil constituencies was reduced from 43 to 40 , with four fewer three-seat constituencies and one more four-seat constituency increasing the average number of seats per Dáil constituency to 3.95, a higher level than that associated with the 2004 and 2007 reports (Figure 1). Indeed, the number of four-seat constituencies (16) recommended in the report is the largest ever number to be associated with a boundary report in the history of the state. The decision taken by the Commission to opt for a total seat number level towards the top of the range available to them attracted some criticism, but this could be defended on the basis that a lower number would have brought the national average representation level very close to the 30,000 


\section{Population per TD}

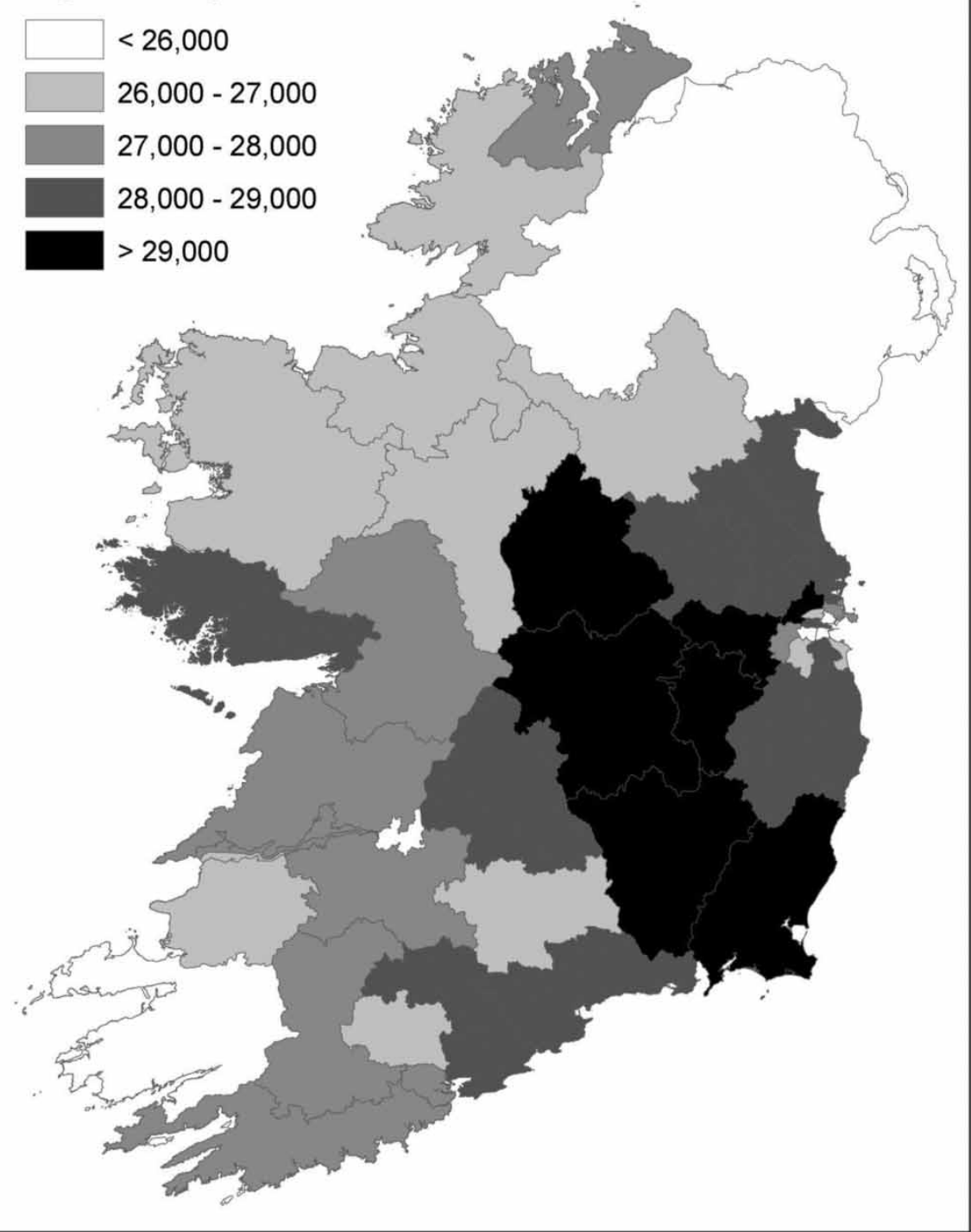

Figure 2. Population per Dáil deputy levels by constituency based on the definitive Census 2011 population by area figures Source: Central Statistics Office (2012). 
limit and could possibly have resulted in challenges as to the constitutionality of the recommendations. It also allowed for some leeway in relation to the continuity provision, with the possibility of this number of seats being maintained in future Constituency Commission revisions even with some further degree of population increase so long as the total state population does not exceed a level of 4.74 million.

Greater stress was placed on the equal representation provision in this report, as compared with the provisions for avoiding the breach of county boundaries and for ensuring continuity with previous Commission reports. Each report is shaped by the differential weightings being applied by different commissions to the proportionality, county boundary and continuity provisions within the terms of reference. While the 1980 Commission placed a greater stress on matching constituency and county boundaries and the continuity provision strongly shaped the recommendations of the 2007 Commission, the 2012 report places much stronger emphasis on the proportionality provision at the expense of the other two. None of the recommended constituencies fell outside the 5 per cent variance limit in terms of how their deputy per population ratios compared with the national average of 29,040, with the maximum levels of variance being associated with Dublin Mid-West $(-4.94 \%)$ and the new five-seat Donegal constituency $(+4.93 \%)$. If greater leeway had been allowed for in relation to constituency deputy per population variances, some breaches of county boundaries could have been avoided, or even mended, including those involving the counties of Galway, Carlow, Meath, Westmeath and Kildare. County boundary breaches involving Offaly, Limerick and Waterford, in addition to the highly contentious political division of Leitrim, were redressed by this report, but new county breaches were to ensue, involving the aforementioned Galway and Kildare cases, as well as other new county boundary breaches involving Tipperary, Mayo, Cavan and Donegal. The report also allowed for the political reunification of Swords Town. While the 2012 Commission appeared to be more tolerant of breaches of county boundaries than previous commissions were, it did extend the rules involving county boundaries to take account of boundaries between local authority areas in Dublin, which proved to be a significant factor in relation to the reshaping of the old Dublin South constituency boundary. The decision to match the constituency boundary between the old Dublin South and Dublin South-West constituencies with that of the local authority boundary between the South Dublin and Dún Laoghaire-Rathdown counties resulted in the transfer of an area equivalent to a population of 39,311, as well as a Dáil seat, from Dublin South to Dublin South-West. The local authority boundary stipulation did not apply as rigorously in other parts of the Dublin region, with a new breach emerging involving the local authority boundaries of Fingal and Dublin City with the transfer of the Ashtown and Phoenix Park areas out of Dublin Central into Dublin West.

In addition to changes effecting the old Dublin South constituency, the creation of five-seat county constituencies for Tipperary, Donegal and Kerry (with these counties previously having been divided into two three-seat constituencies) were among some of the more dramatic changes associated with this report, with territory in north Tipperary and south Donegal also being moved into other neighbouring constituencies in 
order to reduce the population levels of these constituency areas sufficiently for these to become five-seat constituencies. The other new constituency to be created was the five-seat Dublin Bay North constituency, largely comprised of an amalgamation of the old three-seat Dublin North-East and Dublin North-Central constituencies, but with some territory being ceded (Portmarnock and Baldoyle) to the Dublin Fingal constituency. Despite the overall reduction in Dáil seat numbers, some constituencies gained seats, including the Dublin Fingal (formerly Dublin North) and Dublin SouthWest constituencies, as well as the old five-seat Laois-Offaly constituency, which was now to be divided into two new three-seat constituencies, Laois and Offaly. Laois-Offaly had been the only constituency to remain with the same boundaries and seat numbers across all boundary revisions from 1923 to 2007. High levels of population growth in this constituency (and especially in Laois) in the 2000s, however, meant that this constituency ceded some territory to Tipperary North in the 2007 revisions and ceased to exist with the 2012 report. The old three-seat Sligo-North Leitrim constituency also effectively gained a seat, as well as the remainder of Leitrim county and additional territory in Donegal and Cavan counties.

\section{Political Impacts of the Boundary Changes}

The creation of new election boundaries for the next general election has fundamentally altered the rules of the electoral game and sets in play the stage on which the next election campaign will be fought. The base levels of support for different political parties by constituency have been changed, as areas of strong party support are moved into, or out of, different constituencies. Furthermore, changes in seat allocations for constituencies can improve, or reduce, a party's prospects of winning seats in that constituency relative to their support levels in that area. The added dimension of a reduction in the overall Dáil seat levels by eight adds a further potent dimension to the political melting pot, as this ensures that some incumbents are certain to lose their seats at the next general election unless political retirements make up for the shortfall. Looking at the impact of these changes, analyses by Donnelly (2012) and Kavanagh (2012), although differing somewhat in their approaches, both suggested that the extent of Fianna Fáil losses in the 2011 election would have been tempered somewhat had these changes been in place for that election, while the level of gains by the Labour Party and independents would not have been as dramatic. Unlike the Donnelly analysis, which exclusively used figures for the old constituency units, the Kavanagh (2012) analysis was based on amended constituency support figures, taking account of party support level changes arising from movements of territory in and out of constituencies in cases where tally figures are readily available. This analysis estimated that the final party seat levels in the 2011 general election, had the 2012 Constituency Commission report general election boundaries been employed, would have been (the actual seat levels are in parentheses): Fine Gael 74 (76), Labour Party 34 (37), Fianna Fáil 22 (20), Sinn Féin 12 (14), Green Party 0 (0), Independents and Others 16 (19). 
While parties will be affected by constituency changes, individual candidates are more likely to be affected as candidates' electoral prospects may be altered significantly by decisions to increase, or reduce, the numbers of seats in those constituencies as well as the transfer in of new territory from neighbouring constituencies or the transfer out of constituency territory to other neighbouring constituencies. The gain of a seat means that smaller parties have a better chance of winning, or holding, seats at general election contests (although not to the same degree in local elections where candidate factors tend to hold greater weight than party-based voting does), as the addition of an extra seat acts to reduce the percentage share of the vote required to reach the quota in that constituency. On the other hand, the loss of a seat increases the percentage share of the vote required to reach the quota and can make it more difficult for the smaller parties to translate their support levels into seat gains - for instance the loss of two seats involving the new Dublin Rathdown constituency increased the share of the vote required to reach the quota here from $16 \frac{2}{3}$ to 25 per cent. The loss of a seat by a constituency also means that at least one of the incumbents is certain to lose their seat and significantly increases competition levels, almost to the point of making these 'group of death'-type constituencies. The 'last one in' in the previous election, that is, the last candidate who was deemed elected in the election contest in that constituency, may well be viewed as being especially vulnerable in these cases (as indeed proved to be the case with Ciarán Cuffe of the Green Party in Dún Laoghaire in the 2011 election), although it is by no means the case that these candidates will be the ones to lose the seat. For instance, in 2007 Fine Gael's Kieran O'Donnell took the last seat in the Limerick East constituency, and that constituency lost a seat in the subsequent boundary revisions (and was renamed Limerick City). However, instead of being the one to lose out in the following general election, the extent of the swing to Fine Gael (and from Fianna Fáil) at this contest meant that O'Donnell comfortably retained his seat and the seat was instead lost by Fianna Fáil's Peter Power. By contrast, the gain of a seat could possibly make the task of defending a seat at an election decidedly easier. Indeed, despite the level of volatility associated with the 2011 election, the two constituencies that gained extra seats in the 2007 revisions - Dublin West and Louth - were among a small number of constituencies in which none of the outgoing deputies lost their seats. Dublin West was the only constituency to return all the deputies - Joan Burton (Labour), Leo Varadkar (Fine Gael) and the late Brian Lenihan (Fianna Fáil) - who were elected for that constituency in the previous election (2007), with Joe Higgins (Socialist Party) taking the extra seat in that constituency.

Boundary changes also have an impact on candidate prospects when territory transfers are involved. This links in with the concept of the 'friends and neighbours effect'. This argues that a candidate will generally tend to win a significantly larger share of the first preference vote in those areas located in, and close to, that candidate's local base within that constituency, with the candidate's vote share declining the further one moves from the candidate's local base as tantamount to a distance-decay effect (Parker, 1982). Boundary changes that involve the loss of territory by a constituency including part of a candidate's local base will, as a result, significantly reduce that 
candidate's potential vote and possibly have the effect of undermining their prospects of winning a Dáil seat in that constituency. By contrast, a transfer of territory into a constituency that is located close to a candidate's base within that constituency could have the effect of substantially improving their electoral prospects. Territory losses by constituencies arising from the 2012 boundary revisions are likely to see local support being lost by a number of candidates in those constituencies. For instance, the loss of territory by the Mayo constituency to neighbouring Galway West (also resulting in a loss of a seat by Mayo) involves the moving out of an area where the Taoiseach Enda Kenny won over 1,200 votes in the 2011 election, Minister of State Michael Ring won over 1,800 votes and their Fine Gael running mate, John O'Mahony, won nearly 1,000 first preference votes. By contrast, while Fine Gael candidates in Mayo would be losing out on roughly 4,000 of the first preference votes won by them in the 2011 election, this boundary change would be expected to favour Fine Gael candidates in Galway West, such as Seán Kyne, whose political bases would be located close to the area that is being moved in from Mayo.

The changes associated with the 2012 report will also be of interest in terms of their impacts on the implementation of recently introduced gender quota legislation. The overall reduction in the total number of seats means that any increased number of female candidates will ultimately be vying for a smaller number of Dáil seats. In light of the Constituency Commission changes, parties may feel the need to reduce candidate numbers at the next election, but on the other hand gender quota provisions may well require these parties to run a significantly higher number of female candidates, in the process acting to increase parties' overall candidate numbers. Some hard decisions are being posed for a number of the political parties, but especially Fine Gael as that party won 76 seats at the 2011 election, with 65 of these won by male candidates. If all Fine Gael's male incumbents were to contest the next election (excluding Sean Barrett, the Ceann Comhairle), the party would need to run at least 28 female candidates (up from 16 in 2011) in order not to breach the gender quota legislation. The number of female candidates would have to increase further in line with the selection of male aspirants, or non-incumbents. Indeed, if Fine Gael were to run the same number of male candidates (88) as the party did in 2011, then they would have to run 38 female candidates, amounting to an increase of 22 (a 21.2 per cent increase) in that party's total number of candidates relative to the number contesting the 2011 election. Ultimately, the choices left open to parties are to run significantly fewer male candidates (which might require the deselection of male incumbents in some cases) in order to reduce overall candidate levels in light of the Constituency Commission changes or to run an increased number of candidates to absorb the associated increase in female candidate levels. The latter scenario may not be one that the political parties favour, but it is worth noting recent cases where parties have managed to gain or retain seats despite apparently 'running too many candidates', such as Fine Gael in Galway East (2007, 2011), Labour in Galway East (2011), the Progressive Democrats in Galway West $(2002,2007)$ and Fianna Fáil in Laois-Offaly in 2011 (the party did lose a seat in this latter case, but the decision to run three candidates instead of two was instrumental in Fianna Fáil holding two seats in that constituency despite the collapse in Fianna Fáil support 
nationally). If parties were instead to choose to reduce their overall candidate levels in light of the overall reduction in Dáil seat numbers, these parties would be required to reduce significantly their number of male candidates either by blocking the candidatures of male aspirants or possibly by means of the deselection of male incumbents. This, in turn, could lead to a significant increase in the number of gene pool independents at the next election, as disaffected male candidates, who feel they have been unfairly blocked at party selection conventions as a result of the gender quota, may opt to run as independent candidates and could ultimately go on to defeat the official female party candidate in the general election contest, especially if the political context of the next general election is favourable towards independent candidates.

On the other hand, there is a higher percentage vote for females in larger constituencies; female candidates are more likely to make electoral breakthroughs in these, as evidenced from the 2009 local elections, as the data in Table 1 illustrate. The main driver here is the fact that parties are increasingly more likely to select female candidates in the larger constituencies. On this basis, the slight increase in the average constituency size arising from the 2012 Constituency Commission report may make it easier for parties to implement gender quotas, especially in certain constituencies. New opportunities for female candidates to compete successfully for seats may open up in the newly enlarged (amalgamated) constituencies (such as Dublin Bay North, Donegal, Kerry and Tipperary) or in constituencies that effectively gained seats in these boundary redrawals (such as Offaly, Sligo-Leitrim and Dublin Fingal). Evidence from the last local elections showed instances where new female candidates were able to emerge with significant levels of success in local electoral areas that had gained seats, as indeed was the case with the three Dublin Inner City constituencies. Against that, the loss of seats by certain constituencies (such as Dublin Rathdown (the old Dublin South) and Dublin South Central) will pose significant challenges for female aspirants and female incumbents (as indeed for male aspirants and incumbents) contesting these constituencies.

Table 1. Votes/seats won by female candidates in the 2009 local elections (town, county and city council elections) by constituency size

\begin{tabular}{lrrrr}
\hline & $\begin{array}{c}3 / 4 \\
\text { Seats }\end{array}$ & $\begin{array}{c}5 \\
\text { Seats }\end{array}$ & $\begin{array}{c}6 / 7 \\
\text { Seats }\end{array}$ & $\begin{array}{r}9 / 12 \\
\text { Seats }\end{array}$ \\
\hline Female candidates (\%) & 16.9 & 17.3 & 17.3 & 22.7 \\
Female candidates (\%) - political parties & 18.8 & 18.9 & 20.2 & 25.2 \\
Female candidates (\%) - Fianna Fáil/Fine Gael & 15.2 & 17.7 & 18.7 & 26.9 \\
Votes won by female candidates (\%) & 16.7 & 16.8 & 17.3 & 20.4 \\
Seats won by female candidates (\%) & 14.7 & 15.5 & 18.2 & 21.7 \\
First-time female councillors as related to total & 5.5 & 4.5 & 6.5 & 9.5 \\
$\quad$ numbers elected (\%) & & & & \\
\hline
\end{tabular}




\section{Measuring Levels of Constituency Boundary Change}

Many commentators, including this author, have spoken of the 2012 revisions as amounting to the most dramatic changes to general election boundaries in the Republic of Ireland since the 1980 revisions. But can the constituency change level figures for the last eight such revisions be employed to test this contention and can such an analysis pinpoint those constituencies, or areas, which have been especially susceptible to boundary revisions over the past three decades? To be able to answer these questions requires the development of a measure or an index to be able to compare the levels of change involved in different boundary revisions. Such a measure has been devised for the purpose of studying boundary revisions in the United Kingdom by Rallings and Thrasher (2007), with this index of change being used to show that the level of boundary amendment proposed in the 2012 UK Boundary Commissions reports far outstripped those of the previous such revision (Rossiter et al., 2012). Given the different nature of the United Kingdom's electoral system, but most notably the use of single-seat constituencies as opposed to the multipleseat constituencies used in the Irish context, this index of change is not readily applicable to Ireland.

In light of this, I have developed an Irish-specific index of change. The Kavanagh index of constituency change (KICC) produces KICC scores for each boundary revision, as well as for specific regions and individual constituencies, relative to the level of constituency changes involved, with these scores ranging between 1.0 (denoting no changes being made to a constituency boundary) and 6.0 depending on the level of boundary amendments involved. Averaging out these constituency KICC scores for the last eight boundary revisions, as illustrated in Figure 3, proves the contention that the latest set of boundary revisions have had by far the most impact since those brought about in the 1980 report. To some extent, this need not be surprising. Whereas seat levels increased from 148 to 166 in the 1980 revisions, Dáil seat numbers stayed at 166 across the following six revisions, until they were reduced 158 in the 2012 Constituency Commission report. As Figure 3 illustrates, the KICC score of 3.38 for the 2012 revisions shows that the extent of these changes far outstripped those of the preceding six revisions (most of which register KICC scores close to the 2.0 level). The extent of the 2012 revisions, however, paled in comparison with those registered for the 1980 report (with an associated KICC score of 4.19).

Variations in KICC scores can be explained in terms of the 1980 revisions having effectively set the template that would shape boundary configurations across the following six boundary reports, and most of the constituencies set in place by that report were still in place when the 2007 report was published (Constituency Commission, 1980). When new constituencies did emerge, these tended to be the result of amalgamations of constituencies that were in place at the time of the 1980 report, as in the case of the Mayo East and Mayo West constituencies, or the disaggregating of existing constituencies as transpired in the case of the old Kildare and Meath constituencies. Dublin Mid-West was probably the only 'truly new' constituency created during 


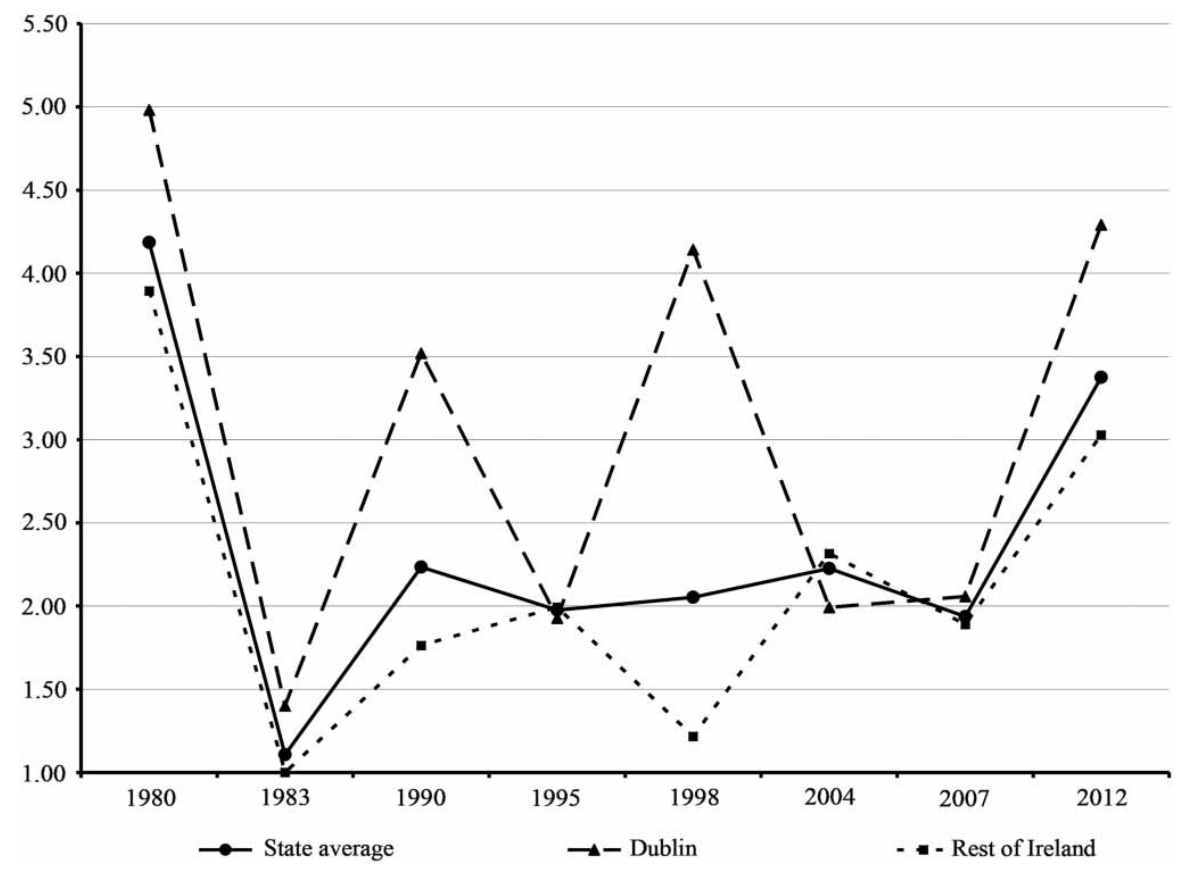

Figure 3. Level of boundary amendments associated with constituency commission reports 1980-2012 as measured by Kavanagh index of constituency change (KICC scores)

this period, having emerged in the 1998 revisions from the amalgamating of parts of the Dublin South-West and Dublin West constituencies. The 2012 revisions have involved significant changes to the boundary template set in place by the 1980 report, however, with the replacing of a number of constituencies created in this report, or prior to it, by a number of new constituency units. Barring further changes to the overall number of Dáil seats (which would necessitate a constitutional change in the case of a further reduction in Dáil seat numbers) or very dramatic changes to the state's population geography, the 2012 report is likely to act as the template on which the next series of boundary revisions will be based, and indeed some of the recommendations in this report would appear to have been made with further revisions in mind. For instance, the creation of the five-seat Tipperary and Donegal constituencies and the three-seat Laois and Offaly constituencies involved breaches of county boundaries that could be redressed in further commission reports if current demographic trends continue and bring these county populations in line with the levels required to allow for an exact match between the county and Dáil constituency boundaries.

Figure 3 also shows that there is an underlying geography involved with these KICC scores, with demographic trends across the state over the three past decades dictating that certain areas and regions were more likely to be affected by boundary changes. A comparison between the KICC scores for the Dublin region and the rest of 
the state shows that, for a number of these revisions, the extent of boundary changes in Dublin has been considerably larger than in the rest of the state, although the score for the rest of the state was somewhat larger for the 2004 revision (in which several new constituencies were created, including the new Meath East and Meath West three-seaters). At the constituency level, even more extreme variations are to be observed in terms of the average scores registered across the eight boundary revisions involved in the period 1980-2012, as illustrated by Table A1. The constituency registering the highest KICC score across this period was Dublin West (4.08), the only constituency whose boundaries have been changed in each of the boundary revisions in this period. A number of other Dublin constituencies also figure among those experiencing the highest level of boundary changes in this period, including Dublin South-Central, Dublin Mid-West, Dublin South-West, Dublin Fingal (North) and Dublin Rathdown (South). Roscommon, or rather the different constituencies that have included the county of Roscommon across this period, including Roscommon, Longford-Roscommon, Roscommon-South Leitrim and Roscommon-Galway, has the highest KICC score of the non-Dublin constituencies, with high scores also being associated with Galway East and Kildare North. At the other end of the scale, the constituencies with the lowest KICC scores were Carlow-Kilkenny and Waterford, two constituencies whose boundaries have remained unaffected by most of the boundary reports produced during this period, with low KICC scores also being associated with the Wexford, Cork South-West and Cavan-Monaghan constituencies.

These KICC score figures are useful as boundary changes also have an impact on ordinary voters and on areas. The high degree of localism associated with Irish politics means that the boundary changes will have an impact particularly on places, given the perception that areas or counties have that it is important to be represented in Dáil Éireann by a representative from the same local area or the same county. But boundary changes may also demobilise populations in the affected areas, if they cannot recognise any of the political representatives in their new constituency or if they are left confused as to which constituency they now find themselves located in following such changes. The geography of KICC scores points in particular to areas, or constituencies, that are especially prone to regular boundary revisions. Such regular boundary changes can demotivate voters from participating in elections in that these will increase the costs of voting in requiring voters to gather information on the different politicians and political issues that will face them in a new constituency, sometimes following each series of boundary amendments. It is perhaps not entirely coincidental that a number of constituencies with higher KICC scores tend also to rank among the constituencies with the lowest voter turnout levels nationally. Research on the low-turnout South-West Inner City (Dublin) area found that local respondents believed that an 'ongoing ... never-ending cascade of changes' to electoral boundaries in the local area played a role in causing low participation levels in this area, while also pointing to instances where local people arrived at their polling stations to find that the people standing for election in their constituency were different from whom they were expecting (Kavanagh, 2002a, 2002b). 


\section{Concluding Considerations}

The process of ratifying the Constituency Commission report is (as of February 2013) ongoing, but there has been little in the way of serious opposition to the proposed changes expressed in the Dáil debates on the 2012 Electoral Act that will put them into effect. This contrasts with the highly contentious debate in the United Kingdom concerning proposed changes to general election boundaries and parliament seats levels there, as attested to in a House of Lords debate on the proposed boundaries:

Despair and anxiety have become the hallmarks of many a political household in the land. While spouses fret, long-term political friendships have become clouded in suspicion. There is an overwhelming feeling of injustice among Britain's MPs, many of whom have spent decades building up relationships with their constituents. At the stroke of a commissioner's pen their lives, careers, family ties, political organisations and loyalties are to be disrupted, leading to widespread insecurity. It is all so unfair. (Lord Campbell-Savours, 2012)

While the process for redrawing electoral boundaries in Ireland mirrors that of the United Kingdom (which uses a first-past-the-post electoral system) - and differs radically from the process in other European countries, which use proportional electoral systems - the process for ensuring equality of representation across different constituencies has proved to be a much more rigorous one in Ireland (Borisyuk et al., 2010). In the United Kingdom, prior to the 2010 Parliamentary Voting System and Constituencies Bill, concerns in relation to ensuring equality of representation aimed to keep variations between constituencies 'within tolerable limits', although the extent of the toleration involved generally remained undefined and continuity and community provisions were generally awarded greater precedence (Johnston et al., 2001: 86). The 2010 Bill effectively would have brought this process more in line with the Irish approach, with stricter rules relating to equality of representation provisions and an increased frequency of boundary reviews along the same lines as the Irish process (Rossiter et al., 2012), in addition to a reduction in the numbers to be elected to the House of Commons from 650 to 600. But, while the Electoral Acts putting Constituency Commission reviews into effect are always passed through the Dáil with very few amendments (usually minor changes, such as amendments to constituency names), if any, this has not proved to be the case in the United Kingdom, and following votes in the Houses of Lords and Commons it has been decided to suspend the implementation of the proposed boundary changes there until after the next general election. Despite the problems and issues surrounding contemporary Irish politics and its history of partisan gerrymanders, it is somewhat heartening that Irish politicians are willing to implement the recommendations of an independent commission without significant change, even when these may well be putting their own political futures at risk. 
As noted above, the Irish boundary review process is different from the approach employed by most other European countries using proportional electoral systems. In a number of these cases, fixed constituency areas equating to existing administrative units are used and the only changes that may occur involve the periodic reassigning of seat numbers on a proportional basis to these constituency units, mainly on the basis of population levels but sometimes also taking account of constituency area and population density concerns (Coakley, 2007). Coakley (2008) has argued that the application of a similar apportionment system could be appropriate to the Irish context. In this case, the constituency boundaries could be fixed on the basis of administrative county boundaries (or an amalgamation of them for smaller counties such as Sligo and Leitrim) and equality of representation would be assured by periodically adjusting seat numbers between constituencies in line with population changes, thus removing the need for long, arduous and administratively demanding boundary redrawal processes following the publication of each census. In this case, he argues, the reapportioning of seats by constituency would merely demand a half hour's work on the part of a numerate civil servant, and the use of fixed constituency units would relieve politicians and voters from the various uncertainties and stresses involved in each boundary revision, as discussed earlier. A change to a process such as this would require changes to be made in terms of the range of seat numbers that can be chosen from for the purpose of allocating these to general election constituencies, but this could be accommodated by means of a change to the Electoral Act.

To conclude, it can be argued that the 'where' matters in electoral politics and especially in Irish electoral politics, given its strong localistic dimensions and tradition of geographical, or 'friends and neighbours', voting. Constituency boundaries, and the redrawing of these, is a key element defining the 'where' of Irish politics and boundary changes do have an impact on political contests at the national level, but especially at the local, or constituency, level. The significant changes brought about in the 2012 Constituency Commission report - reducing Dáil seat numbers by eight and encompassing a range of boundary amendments that involve the majority of existing Dáil constituencies - will notably alter the Irish political landscape in the lead-up to the next general election. The boundary changes also have the potential to affect the success levels of new political reform initiatives, such as the gender quota legislation, and indeed it could also be argued that boundary revisions, or changes in the approach taken to them, could play a role in facilitating these and number of other political reform initiatives. But just as contentions that the Republic of Ireland has too many members of parliament cannot be addressed without the holding of a referendum, other changes to the terms of reference set for Constituency Commissions will require changes in legislation and amendments of the existing Electoral Acts. One aspect that could be focused on is the limitations placed on Constituency Commissions in terms of the range of Dáil constituency seat numbers they can award to constituencies. The relatively small district magnitude associated with Irish election constituencies limits the degree of proportionality associated with the system and 'ensures that the large parties gain and the small ones lose consistently' in this regard (Gallagher, 1986: 259), but this is also a 
concern given the evidence that larger constituencies can act to facilitate the electoral participation levels of female candidates, in addition to those from minority groups. Thus, it is important that the topic of electoral boundaries should also form a part of political reform discourse in the Republic of Ireland over the coming years and the Irish parliament be prepared to enact legislative change where it is deemed desirable to change the rules shaping the redrawing of election boundaries in order better to facilitate political reform processes.

\section{References}

Borisyuk, G., Johnston, R., Rallings, C. \& Thrasher, M. (2010) Parliamentary constituency boundary reviews and electoral bias: how important are variations in constituency size?, Parliamentary Affairs, 63(1), pp. 4-21.

Carolan, M. (2007) Court dismisses claim over revision of constituencies, The Irish Times, 8 June, pp. 7. Carty, E. (2007) Judge calls for 'urgent' review of electoral boundaries, Irish Independent, 8 June, pp. 9.

Central Statistics Office (1950) Census of Population of Ireland 1946 Volume 1: Population, Area and Valuation of each District Electoral Division and of each Larger Unit of Area (Dublin: The Stationery Office).

Central Statistics Office (1957) Census of Population of Ireland 1956: Population, Area and Valuation of each District Electoral Division and of each Larger Unit of Area (Dublin: The Stationery Office).

Central Statistics Office (2007) Census 2006: Principal Demographic Results (Dublin: The Stationery Office).

Central Statistics Office (2012) Census 2006: Principal Demographic Results (Dublin: The Stationery Office).

Coakley, J. (2007) Revising Dáil constituency boundaries: Ireland in comparative perspective, Administration, 55(3), pp. 1-30.

Coakley, J. (2008) Does Ireland need a Constituency Commission?, Administration, 55(4), pp. 77-114.

Coleman, S. (2007) Up The Poll: Great Irish Election Stories (Dublin: Mentor Books).

Collins, S. (2001) The Power Game: Ireland Under Fianna Fáil (Dublin: The O'Brien Press).

de Bréadún, D. (2009) Dáil could be cut by 20 seats - Kenny, The Irish Times, 24 July, pp. 8.

Constituency Commission (1980) Dáil Éireann Constituency Commission Report 1980 (Dublin: The Stationery Office).

Constituency Commission (2012) Constituency Commission Report 2012: Dáil and European Parliament Constituencies (Dublin: The Stationery Office).

Donnelly, S. (2012) Projection of 2011 Result on 2012 Constituencies, available at: http://electionsireland. org/documents/2012boundaryprojection.pdf (accessed 23 August 2012).

Gallagher, M. (1986) The political consequences of the electoral system in the Republic of Ireland, Electoral Studies, 5(3), pp. 253-275.

Johnston, R., Pattie, C., Dorling, D. \& Rossiter, D. (2001) From Votes to Seats: The Operation of the UK Electoral System since 1945 (Manchester: Manchester University Press).

Kavanagh, A. (2002a) Unequal Participation, Unequal Influence: Voter Participation and Voter Education in Dublin's South West Inner City (Dublin: South West Inner City Network).

Kavanagh, A. (2002b) Social Deprivation, Political Alienation and Community Empowerment, PhD Thesis, NUI Maynooth.

Kavanagh, A. (2012) Estimating 2011 General Election Seats Levels Using New Constituency Commission 2012 Election Boundaries, available at: http://adriankavanaghelections.org/2012/07/06/ ge11partyseats2012constitcommboundaries/ (accessed 23 August 2012).

Lord Campbell-Savours (2012) Hansard - House of Lords Debates, col. 1258, 12 July.

Parker, A. J. (1982) The 'friends and neighbours' effect in the Galway West constituency, Political Geography Quarterly, 1(3), pp. 243-262. 
Rallings, C. \& Thrasher, M. (2007) Media Guide to the New Parliamentary Constituencies (Plymouth: Local Government Chronicle Election Centre).

Rossiter, D., Johnston, R. \& Pattie, C. (2012) Representing people and representing places: community, continuity and the current redistribution of parliamentary constituencies in the UK, Parliamentary Affairs, first published online 3 July 2012, doi: 10.1093/pa/gss037.

\section{Appendix: The Kavanagh Index of Constituency Change}

The KICC produces KICC scores for each boundary revision, as well as for specific regions and individual constituencies, relative to the level of constituency changes involved, with these scores ranging between 1.0 (denoting no changes being made to a constituency boundary) and 6.0 depending on the level of boundary amendments involved. Constituencies in which no boundary revisions have taken place in a particular Constituency Commission review are allocated a score of 1.0. The constituency KICC scores are weighted by a factor of 3.0 if a new constituency has been created in the process or if that constituency loses or gains at least one seat. The new constituency weighting was reduced to 1.00 in cases where the creation of a new constituency effectively amounted to the renaming of an existing constituency and where the territory/population transfers involved proved to be quite limited (less than 10,000 population). The score is weighted further by a factor of between 1.5 and 3.0 depending on the level of population transfers involved if territory is being gained and/or lost by a constituency. Minor changes, where the combined total level of population being moved into, and out of, the constituency arising from the different boundary changes having an impact on this is less than 5,000. This weighting increases to:

1. 2.0 for changes involving between 5,000 and 10,000 population;

2. 2.2 for changes involving between 10,000 and 15,000 population;

3. 2.4 for changes involving between 15,000 and 20,000 population;

4. 2.6 for changes involving between 20,000 and 25,000 population;

5. 2.8 for changes involving between 25,000 and 30,000 population;

6. 3.0 for changes involving greater than 30,000 population.

The individual scores for each constituency are then averaged out to produce the overall average KICC score associated with specific Constituency Commission reports.

KICC scores for the individual constituencies across the eight Constituency Commission reports published since 1980 have been averaged out to produce an overall estimate for each of these, as noted in Table A1. The constituency units used here are those that were in existence on more than half, at least, of the occasions on which these reports were published. 


\section{A. Kavanagh}

Table A1. KICC scores by Dáil constituency, averaged across the 1980, 1983, 1990, 1995, 1998, 2004, 2007 and 2012 boundary revisions

Constituency

Average KICC score

Carlow-Kilkenny

Cavan-Monaghan

Clare

1.65

Cork East

1.68

Cork North-Central

2.74

Cork North-West

2.24

Cork South-Central

2.65

Cork South-West

1.50

Donegal North-East

2.23

Donegal South-West

Dublin Central

Dublin Mid-West

Dublin North (Fingal)

3.15

Dublin North-Central

2.90

Dublin North-East

3.06

Dublin North-West

2.70

Dublin South (Rathdown)

3.10

Dublin South-Central

3.56

Dublin South-East (Dublin Bay South)

2.58

Dublin South-West

Dublin West

4.08

Dún Laoghaire

2.50

Galway East

Galway West

2.09

Kerry North

2.28

Kerry South

Kildare North

Kildare South

2.73

Laois-Offaly

1.66

Limerick City/Limerick East

2.39

Limerick County/Limerick West

2.43

Longford-Westmeath

2.33

Louth

1.61

Mayo

2.34

Meath East

2.45

Meath West

2.38

Roscommon-(South Leitrim/Longford/East Galway)

3.09

Sligo-Leitrim

2.76 
Table A1. (Continued).

Constituency

Tipperary North

Tipperary South

Waterford

Wexford

Wicklow
Average KICC score

1.91

2.65

1.19

1.44

2.18 